\title{
Online Education during Covid-19: A Safe and Effective Way of Learning Research Techniques from a Mentor
}

\author{
Ameer Ali \\ IELL, University of Sindh, Jamshoro, Pakistan \\ Maya Khemlani David \\ Asia-Europe Institute, University of Malaya, Kuala Lumpur, Malaysia
}

\begin{abstract}
The Covid-19 pandemic has changed social mechanisms of our world causing many countries to impose either partial or complete lockdowns. Consequently, many people have resorted to online platforms for undertaking their daily business activities and jobs. Similarly, there is also an increasing trend of online education followed by both teachers and students around the world. Therefore, the aim of this research paper is to explore how a mentee learnt research techniques from a mentor through online platforms. Although researchers have studied the challenges and opportunities of online education during the pandemic, this research will explore how the mentee learnt research techniques from the mentor through emails, WhatsApp interaction, and Microsoft Word track changes feature. In this paper, we have used experiential research methodology for carrying out research. Employing qualitative method of data analysis, we have found out that the feedback and suggestions provided by a mentor to a mentee's research work through the online platforms have been very safe and effective in improving the mentee's research skills. Moreover, purposively selected chunks from the mentee's six revised drafts have been discussed to demonstrate how online education facilitates practical learning during the pandemic. Finally, we are of the view that online platforms may be used as effective pedagogical tools because these facilitate learners to read their mentor's feedback and suggestions as many times as they desire to improve their performance.
\end{abstract}

Key words: Covid-19; Mentor; Mentee; Online Education; Research Techniques

\section{INTRODUCTION}

In December 2019, the novel coronavirus started spreading infectiously from one person to another forcing many countries to impose lockdowns and to prevent the spread of the pandemic. This imposition of lockdowns disrupted social routines causing people to maintain physical distance to guard themselves against the lethal virus. Moreover, many people around the world shifted their social activities and professional jobs to online platforms to sustain their needs and wants. Similarly, educational institutions also relied upon online platforms to achieve their aims and objectives. Providing education through online platforms and digital means boosted during the pandemic. Both teachers and students collaboratively interacted with each other through conference calls, zoom meetings, WhatsApp interaction, and emails to make learning happen effectively. These online platforms made learning both safe and effective in the wake of Covid19.
This emerging trend of education also provided the Pakistani mentee with a much-needed opportunity to learn research techniques from the Malaysian mentor. One day, the mentor shared a Facebook post entitled as 'For my Angels' in which there was a call from a research journal for submission of research papers on any of the given topics. The mentee was interested in one of the topics, however, his research skills needed to be polished to produce a quality research paper. Therefore, he showed want and need of working on one of the chosen topics under the supervision of his mentor. In this regard, they chose to work on a joint research paper. The mentor gave him guiding suggestions on how to write a research paper which he afterwards worked on and sent her through email. Furthermore, they decided to make learning more practical which, perhaps, would not have been possible without the online communication and interaction. Both the mentor and the mentee live in two far distant countries, but thanks to the online platforms they have been able to overcome the distance. Then, the mentor gave him further suggestions and feedback using the 'track changes' feature of

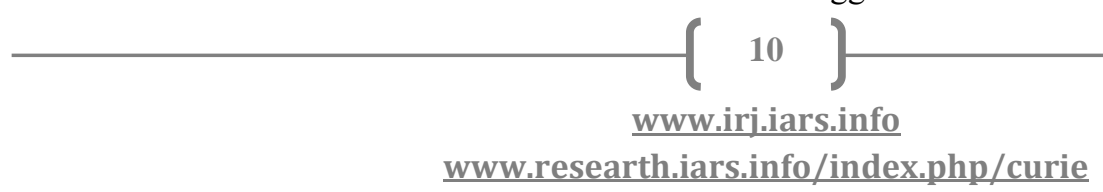




\section{Yinternational Research Journal}

p-ISSN 2202-2821 e-ISSN 1839-6518 (Australian ISSN Agency)

Microsoft Word. They also used different media of communication, such as email, WhatsApp, and Facebook and many online research websites including Academia, ResearchGate, and Google Scholar which facilitated their educational goals and objectives effectively. Utilizing all these online platforms along with the mentor's constructive feedback, the mentee developed six drafts of the research paper all of which reflected consecutive improvement.

During the Covid-19, the educational institutions world over went off causing many of the people to stay at home and stay safe. The pandemic made them go online and thus the mentee explored many opportunities of learning online. Besides, the mentor is from Kuala Lumpur, Malaysia, and the mentee is from Sindh, Pakistan. Their countries are very distant from each other. However, they overcame the distance through the online communication in the wake of Covid-19. Therefore, the aim of this research paper is to trace the consecutive improvement which the mentee embarked upon considering the mentor's feedback and suggestions. We will explore the processes of improvement by analyzing the purposively chosen chunks taken from all the drafts which were modified considering the suggestions and feedback. All the drafts which they collaboratively developed were about language policy and politics of languages of Pakistan.

\section{Research Questions}

What research suggestions and feedback did the mentor give to the mentee?

What online platforms and digital means did they use to make learning happen effectively?

How did the mentee incorporate his mentor's suggestions in the joint research paper?

How did the mentor help him in improving the six consecutive drafts?

\section{Conceptual Framework}

We have developed a functional, conceptual framework based on the interaction and discussion the mentee and the mentor carried out throughout the systematic process of learning and hence improving the six consecutive drafts. We will use this conceptual framework in discussing and analyzing the research findings. The framework of analysis is described here:

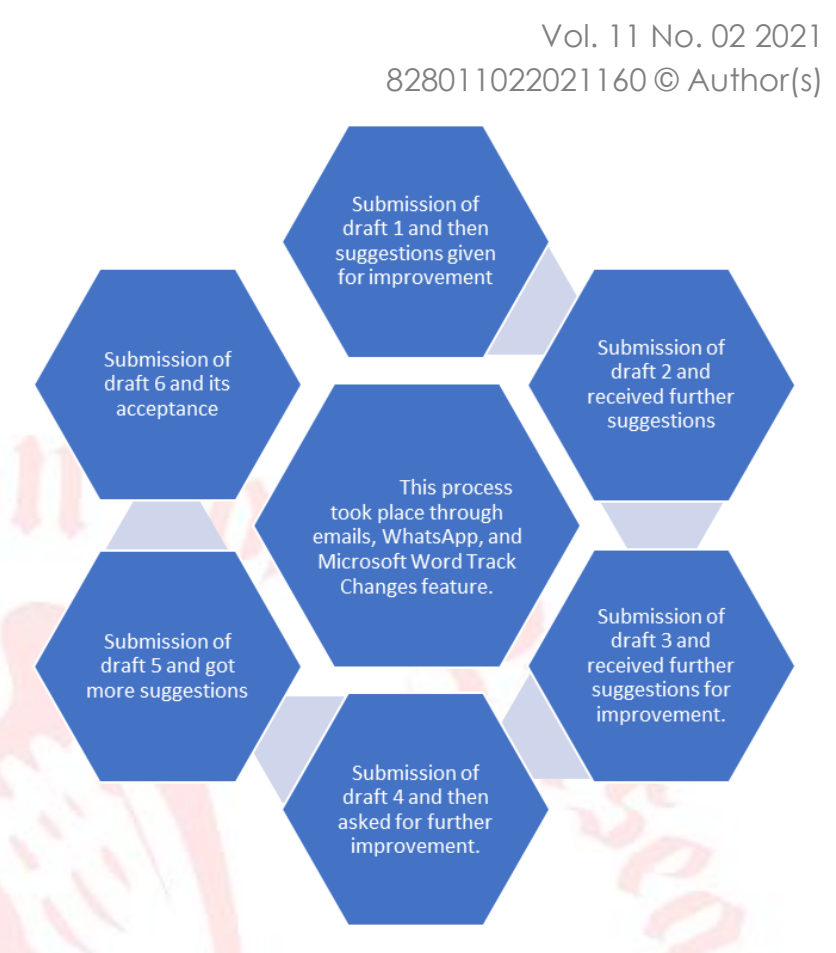

Figure 1: The Improvement Process

This process of learning was a continuous interaction in which both the mentor and the mentee were involved through online means such as email, and WhatsApp. Moreover, they also collaboratively made use of digital means such as track changes feature of Micro Soft Word which enabled them to effectively share their views and responses. The mentor used the track changes feature as a pedagogical tool through which she wrote very informative comments on the mentee's research draft which he later incorporated into the paper to improve its quality. We have classified the mentoring suggestions into ten categories based on their aims and guidelines. All these categories of suggestions which were shared through the online platforms and the digital means are described here:

\section{A. Suggestions pertaining to theoretical framework}

Almost all the suggestions which the mentee got from his mentor were given to rectify the mistakes which the mentee had made in the research paper. First, the mentee did not include the theoretical framework which he was supposed to use in the paper. This was indeed a blunder. Thus, the mentor told him to describe and use the known theoretical framework in his paper. The mentor also specified the place where the mentee should put the framework in the research paper. Hence, the mentor gave the mentee suggestions with respect to improving the section on the theoretical framework.

\section{B. Suggestions pertaining to sequence}

The other type of suggestions which the mentor gave to the mentee were about properly sequencing the paper, especially, 
the section on the data analysis. In fact, the mentee had written the data analysis section in a disorderly manner. Therefore, the mentor guided the mentee to follow both geographical and temporal parameters of sequence in the data analysis section of the paper.

\section{Suggestions pertaining to delimiting the scope of the research paper}

The mentor also suggested the mentee to delimit the scope and focus of the research paper to the country of his residence, Pakistan.

\section{Suggestions pertaining to literature review}

In addition, the mentor also suggested the mentee to make the literature review more relevant to Pakistan.

\section{E. Suggestions about avoiding sweeping statements}

In the earlier research drafts, the mentee made sweeping statements with respect to the work of other writers. Consequently, the mentor asked the mentee to town down such words like always, never, and not to use wide sweeping statements.

\section{F. Suggestions pertaining to discussion section}

The mentee had written a very short section on discussion, so his mentor suggested an elaboration and provided how this could be done.

\section{G. Suggestions pertaining to citations and references}

The mentor also suggested that the mentee should cite relevant research works where it was necessary to do it. The mentor also instructed the mentee to check in text citations against the sources mentioned in the reference list.

\section{H. Suggestions pertaining to the tone of criticism}

The mentee's tone of criticism of the research work which he had reviewed was harsh, so the mentor suggested him to soften it.

\section{Suggestions about proof reading}

The mentor also instructed the mentee to proofread the article against errors and mistakes.

\section{J. Suggestions pertaining to plagiarism}

Since the mentee was a novice researcher, he did not know that some journals required the writer to provide data regarding similarity index. The mentor taught him about research ethics, and how the mentee can check plagiarism on the research paper using turn it in.

\section{0 (C) Author(s)}

All the above given suggestions were given through online platforms and digital means as discussed above. Moreover, all the improvements incorporated in the six drafts have been analyzed in correspondence with the respective suggestions given by the mentor. The improvement process has been traced and evaluated as shown in the figure 1 given above.

\section{Literature Review}

Many researchers have studied the influence of Covid-19 on the modes of imparting education (Bhuwandeep and Das, 2020; Khezrimotlagh, 2020; Patra and Sahu, 2020). Bhuwandeep and Das (2020) have qualitatively reviewed about one hundred Scopus indexed research works on the thematic emergence of education in the wake of Covid-19. They found out that blended learning has emerged as a widely used mode of teaching and learning online (Bhuwandeep and Das, 2020: pg. 6). These researchers view blended learning as an emergency response adopted by educational institutes during Covid-19. However, this effective, pedagogical mode has been already used to reduce learning and communication distance even before the pandemic occurred. Furthermore, the context of experience-based learning of research techniques from a mentor through digital media and communication has not been much explored.

In addition to Bhuwandeep and Das (2020), Khezrimotlagh (2020) drew upon personal experiential methodology and qualitatively assessed the impacts of online learning during the pandemic. He argues that online education is ineffective because it does not facilitate students with required skills to face the future challenges (Khezrimotlagh, 2020: pg. 13). Instead, he suggests the use of hybrid education which he thinks "can be a reasonable solution in this pandemic. The hybrid design provides [solid] learning opportunities to experience both in-person learning and online digital learning" (Khezrimotlagh, 2020: 14). Although his suggestion is reasonable, but it is obviously not applicable when both the teacher and the learner live in two distant areas or countries and thereby in-person teaching is not possible. Additionally, Khezrimotlagh's experience-based findings generally deal with the broader area of education, however, the area of learning research skills from a mentor through hybrid means of education is yet to be explored.

Unlike Khezrimotlagh (2020), Patra and Sahu (2020) used quantitative, secondary data and analyzed it to describe the benefits of online education during the pandemic. They found out that online education is the most popular way of teaching and learning in schools and colleges after the pandemic disrupted the traditional ways of education (Patra and Sahu, 
2020). Moreover, they also say that through online education "the regular assignment, screen shared materials and interaction between teachers and students reflects "regular" class feeling" (Patra and Sahu, 2020: 46). Online education also results in less travelling time for both teachers and students (Patra and Sahu, 2020). Patra and Sahu have demonstrated the advantages of online education, such as ease of access to education and thereby ease of dissemination of knowledge, however, the use of online educational tools for teaching and learning research techniques during Covid-19 has not been discussed in their research work.

Much more relevant than the above given findings are the research work of Nicola Byrom (2020) who employed quantitative, secondary data and qualitatively analyzed the data to illustrate the challenges faced by early-career researchers in the United Kingdom. She found out that the early-career researchers are facing issues of research impairment, and poor mental wellbeing (Byrom, 2020). Byrom's discussion is confined to the challenges posed by the new normal, however, the pandemic has also resulted in online opportunities of learning from great scholars from all over the world.

Additionally, Nusantari (2020) has qualitatively evaluated the challenges associated with digital literacy. Nusantari's research work deals with socio-emotional literacy, while the role that digital literacy is playing in the development of the research learners under the supervision of their mentors has not been discussed. Therefore, it is the aim of this research paper to explore the role of online, digital platforms in facilitating novice researchers to learn from their learned mentors through email exchange, WhatsApp interaction, and other online platforms.

\section{Methodology}

This research is qualitative, descriptive in its design and method. It employs experiential methodology drawing upon the data from the six drafts which the mentee produced under his mentor's guidance and supervision. It was through Facebook, emails, and WhatsApp that the mentee approached his mentor, and his journey of learning research techniques began online in a virtual world. They used email for exchanging the revised drafts and sharing feedforward and feedback. If there was a further need for discussion on a point, they resorted to WhatsApp messages. When necessary, the mentor would also call the mentee on WhatsApp if a particular point in a section needed much explanation and elaboration. The process of learning and producing the six drafts through the suggestions took place over a month. The purposively chosen chunks from the mentor's comments and suggestions (within track changes) and the corresponding modifications from the mentee's research drafts have been thematically analyzed to illustrate and elaborate the process of learning research techniques and skills through online, digital means.

\section{Findings and their Analysis}

In this section, the research findings have been analyzed based upon the mentor's suggestions and the mentee's corresponding improvements in the consecutive six research drafts.

\section{A. Analyzing the suggestion-based improvement of Draft 2}

In this segment, the data has been tabulated to systematically show and analyze the research findings as shown in Table-1.

\begin{tabular}{|l|l|l|l|}
\multicolumn{5}{|c}{ Table 1: Research Findings 1 } \\
\hline $\begin{array}{c}\text { S. } \\
\text { No. }\end{array}$ & $\begin{array}{c}\text { The Mentee's } \\
\text { Novice Attempts. }\end{array}$ & $\begin{array}{l}\text { The Mentor's } \\
\text { Suggestions. }\end{array}$ & $\begin{array}{l}\text { The Manner of } \\
\text { Mentee's Improvement. }\end{array}$ \\
\hline 1. & $\begin{array}{l}\text { Not defined } \\
\text { research limits. }\end{array}$ & $\begin{array}{l}\text { Delimit research } \\
\text { area. }\end{array}$ & $\begin{array}{l}\text { Delimited his research to } \\
\text { the context of Pakistan. }\end{array}$ \\
\hline 2. & No proofreading. & Proof reading. & $\begin{array}{l}\text { Rectified the errors and } \\
\text { the mistakes. }\end{array}$ \\
\hline 3. & Generalizations. & $\begin{array}{l}\text { Toning down } \\
\text { such statements. }\end{array}$ & $\begin{array}{l}\text { Reduced sweeping } \\
\text { statements. }\end{array}$ \\
\hline 4. & $\begin{array}{l}\text { Disorganized } \\
\text { research. }\end{array}$ & $\begin{array}{l}\text { Sequential } \\
\text { arrangement. }\end{array}$ & $\begin{array}{l}\text { Reorganized the paper so } \\
\text { that it was both cohesive } \\
\text { and coherent. }\end{array}$ \\
\hline 5. & Severe criticism. & $\begin{array}{l}\text { Softened } \\
\text { criticism. }\end{array}$ & $\begin{array}{l}\text { Used hedges to soften the } \\
\text { tone of criticism. }\end{array}$ \\
\hline 6. & $\begin{array}{l}\text { Irrelevant literature } \\
\text { review. }\end{array}$ & $\begin{array}{l}\text { Relevant } \\
\text { literature } \\
\text { review. }\end{array}$ & $\begin{array}{l}\text { Removed the irrelevant } \\
\text { reviews and added the } \\
\text { relevant ones. }\end{array}$ \\
\hline
\end{tabular}

The first research draft which the mentee produced contained many weak areas which needed to be improved. The mentee sent the draft to his mentor through email. The first draft did not clearly define the scope of the research paper. The mentee vaguely discussed in the background section that the research paper would deal with the language policies and politics of India and Pakistan. The mentor, based on her experience, gave the mentee a suggestion through email to delimit the research area and scope. Consequently, the mentee delimited the scope of his research to the context of language policies and politics of Pakistan. Additionally, the mentee had not proofread his first draft, and many of the mistakes escaped the mentee's attention. When the mentor read the draft, she turned the mentee's attention to the errors using the track changes feature of MS Word. When the mentee saw the track changes, he was able to track the errors easily. Accordingly, he rectified the mistakes and errors as suggested by his mentor.

In this way, the mentee came to understand the importance of being patient when doing research. Moreover, the mentee's research draft was written in a disorderly way, so the mentor used digitized means and gave suggestions about properly 


\section{Yinternational Research Journa}

p-ISSN 2202-2821 e-ISSN 1839-6518 (Australian ISSN Agency)

sequencing the mentee's research work. The mentee improved the sequence; however, it was after several attempts that the mentee internalized the art of sequencing a systematic research paper. Moreover, in the literature review section of the first draft, the mentee was very harsh in criticizing the works of other scholars. Using the track changes feature the mentor emailed him the suggestion of softening the tone of his criticism.

Furthermore, much of the mentee's review of the literature was irrelevant. It did not deal with the literature on the language policies and politics in Pakistan's context. The mentee first reviewed literature on different countries' language policies and then discussed the literature on Pakistan's language policies. He was assuming that he was going from general to specific, while his assumption was misleading him to write and review irrelevant research papers. Therefore, the mentor rectified the mentee's mistake and asked him to be relevant and specific.

\section{B. Analyzing the suggestion-based improvement of Draft 3}

The suggestion-based improvement of the draft 3 has been analyzed in this section using the tabulated data as shown in Table-2.

All the learning process given in the table took place through online means such as email, and WhatsApp, and the track changes feature of MS Word due to the pandemic.

In the introductory section that the mentee wrote he did not use the relevant citations. He only assumed a stance without citation. He wrote: "The politics of language polarized around the Urdu-Hindi controversy which was fueled by the institutionalized 'divide and rule' policy of the British colonial government". This statement does not contain the citation which the mentee should have given. Therefore, using the track changes feature of MS Word, the mentor wrote a guiding comment attached with the above quoted statement: "cite a source". Accordingly, the mentee searched through different databases and came up with a relevant citation. This comment was made by the mentor several times and almost all the time the mentee made the suggested changes. These suggestions also taught the mentee to be careful in how he cited certain sources. When citing a source, he had to Ensure that what he said was a correct and accurate paraphrase of what the source cited had said/written.

The mentee not only missed the relevant citations but also did not explain the key words which he was to use throughout the research paper. The words, for instance, critical junctures, path dependency, institutionalist traditions, and language regimes, were central to the paper but the mentee did not explain their meaning and concepts associated with them. Consequently, the mentor suggested: "Perhaps since you have mentioned them you should then go on in the next paragraph or section [and] state their approach. Also, provide definitions of the terms like critical juncture...". Then, the mentee incorporated these suggestions into his introductory section and improved the section by further clarifying it.

Table 2:Research Findings 2

\begin{tabular}{|c|c|c|c|}
\hline Section \# & $\begin{array}{l}\text { What the Mentee } \\
\text { Did. }\end{array}$ & $\begin{array}{l}\text { What the Mentor } \\
\text { Suggested. }\end{array}$ & $\begin{array}{l}\text { How the Mentee } \\
\text { Improved. }\end{array}$ \\
\hline 1. Introduction. & $\begin{array}{l}\text { 1. Gave no } \\
\text { citations where } \\
\text { necessary. } \\
\text { 2. Did not explain } \\
\text { key words. }\end{array}$ & $\begin{array}{l}\text { 1. Suggested citing } \\
\text { relevant research } \\
\text { works. } \\
\text { 2. Suggested } \\
\text { explaining the } \\
\text { keywords. }\end{array}$ & $\begin{array}{l}\text { 1. Modified his } \\
\text { stances and gave } \\
\text { relevant citations to } \\
\text { avoid plagiarism. } \\
\text { 2. Explained the } \\
\text { keywords. }\end{array}$ \\
\hline $\begin{array}{l}\text { 2. Literature } \\
\text { Review. }\end{array}$ & $\begin{array}{l}\text { 1. Put some } \\
\text { irrelevant } \\
\text { paragraphs. } \\
\text { 2. Did not } \\
\text { mention names of } \\
\text { researchers. }\end{array}$ & $\begin{array}{l}\text { 1. Suggested that } \\
\text { certain paragraphs } \\
\text { should be placed } \\
\text { elsewhere so that } \\
\text { there was a logical } \\
\text { sequential flow. } \\
\text { 2. Suggested to give } \\
\text { the names of } \\
\text { sources cited. }\end{array}$ & $\begin{array}{l}\text { 1. Moved the } \\
\text { paragraphs to their } \\
\text { relevant places. } \\
\text { 2. Provided the last } \\
\text { names of all the } \\
\text { skipped authors. }\end{array}$ \\
\hline 3. Methodology. & $\begin{array}{l}\text { 1. Put in the } \\
\text { wrong place. }\end{array}$ & $\begin{array}{l}\text { 1. Suggested to put } \\
\text { it after the } \\
\text { introductory } \\
\text { section. }\end{array}$ & $\begin{array}{l}\text { 1. Put it after the } \\
\text { introductory } \\
\text { section. }\end{array}$ \\
\hline 4. Data Analysis & $\begin{array}{l}\text { 1. Did not } \\
\text { adequately } \\
\text { explain some } \\
\text { concepts. } \\
\text { 2. Did not } \\
\text { mention key } \\
\text { events. } \\
\text { 3. no sequence. } \\
\text { 4. Did not connect } \\
\text { relevant concepts } \\
\text { and events in the } \\
\text { analysis section. } \\
\text { 5. Did not show } \\
\text { the ethnolinguistic } \\
\text { identity. } \\
6 . \text { Implied that } \\
\text { words were said } \\
\text { by some writers } \\
\text { who did not, in } \\
\text { fact, say them. } \\
7 . \text { Did not } \\
\text { factcheck his } \\
\text { assumptions. }\end{array}$ & $\begin{array}{l}\text { 1. Suggested } \\
\text { explanation. } \\
\text { 2. Suggested to } \\
\text { mention the key } \\
\text { events which } \\
\text { included critical } \\
\text { junctures. } \\
\text { 3. Asked to add } \\
\text { sequence properly. } \\
\text { 4. Suggested him to } \\
\text { connect and } \\
\text { compare events to } \\
\text { sharpen the } \\
\text { criticality of his } \\
\text { analysis. } \\
\text { 5. Asked him to } \\
\text { discuss the } \\
\text { ethnolinguistic } \\
\text { identity. } \\
6 \text {. Asked the mentee } \\
\text { to restrict his ultra- } \\
\text { subjective } \\
\text { assessment. } \\
\text { 7. Instructed the } \\
\text { mentee to factcheck } \\
\text { his assumptions. }\end{array}$ & $\begin{array}{l}\text { 1. Clearly } \\
\text { explained the } \\
\text { terms. } \\
2 \text {. Added the key } \\
\text { events accordingly. } \\
\text { 3. Changed the } \\
\text { sequence } \\
\text { accordingly. } \\
4 \text {. Made } \\
\text { connections } \\
\text { between events and } \\
\text { thus improved } \\
\text { analytical skills. } \\
5 \text {. This further } \\
\text { clarified the politics } \\
\text { of languages of } \\
\text { Pakistan. } \\
6 \text {. Restrained his } \\
\text { subjectiveness. } \\
\text { 7. Cited relevant } \\
\text { research works and } \\
\text { modified his } \\
\text { stance. }\end{array}$ \\
\hline $\begin{array}{l}\text { 5. Discussion and } \\
\text { Concluding } \\
\text { remarks }\end{array}$ & $\begin{array}{l}\text { 1. Repeated the } \\
\text { same points in } \\
\text { different words. }\end{array}$ & $\begin{array}{l}\text { 1. Asked the mentee } \\
\text { to strengthen this } \\
\text { section by learning } \\
\text { from the section on } \\
\text { discussion in } \\
\text { SCOPUS Journals. }\end{array}$ & $\begin{array}{l}\text { 1. Read discussion } \\
\text { sections of } \\
\text { SCOPUS journals } \\
\text { and accordingly } \\
\text { improved the } \\
\text { section in his paper. }\end{array}$ \\
\hline 6. References & $\begin{array}{l}\text { 1. Did not check } \\
\text { the citations } \\
\text { against the } \\
\text { references. }\end{array}$ & $\begin{array}{l}\text { 1. Suggested to } \\
\text { check the citations } \\
\text { against the } \\
\text { references. }\end{array}$ & $\begin{array}{l}\text { 1. Checked the } \\
\text { citations against the } \\
\text { references and } \\
\text { added the missing } \\
\text { references. }\end{array}$ \\
\hline
\end{tabular}

Much like the introductory section, the methodology section of the paper also needed much improvement. The mentee was unaware where to put it in the research paper. When the 


\section{Yinternational Research Journal}

p-ISSN 2202-2821 e-ISSN 1839-6518 (Australian ISSN Agency)

mentor checked the sequence of the methodology, she tracked it using the MS Word feature and engaged the mentee into rethinking the methodology and relocating it into the place where it belonged to. This MS Word track changes feature helped the mentee in learning by doing. It was through the track changes that the mentee interacted with his mentor since it was a much safer and much more effective way of learning research during the pandemic.

In addition to the incongruent way of writing methodology, the mentee also made novice attempts in writing literature review. First, he included some irrelevant paragraphs in this section which should have been embedded in the introductory segment of the paper. In one of the paragraphs the mentee gave introduction of a political leader and his policy statements. He added the paragraph in the literature review section because he thought it would clarify the beginning of the politics of languages of Pakistan. However, the mentor using the track changes suggested the mentee to exclude the paragraph, because in the section on literature the mentee was required to review research works. Only then, the mentee realized what to include and what to exclude from the literature review section. Moreover, in the section the mentee had skipped the names of the researchers like 'Ali et al.' even though he mentioned them for the first time. Using the track changes feature, the mentor suggested the mentee not to skip the names of the researchers and thus the mentee also improved the art of mentioning the names of all the researchers who had jointly published a paper.

The mentee did not describe the key concepts and took it for granted as if the readers would know those concepts. Therefore, the mentor tracked those words and suggested an explanation of those words. Afterwards, the mentee explained the words in the background section. Moreover, the mentee had not mentioned the key events that were related to his research. Therefore, the mentor employed track changes to suggest the mentee to include and discuss the key events in the relevant places of the data analysis section of the paper. For instance, the mentor wrote a comment: "Mention 21 February and students who were killed. Cite some from the data sources mentioned". Thus, the mentee incorporated the suggestion in an appropriate section of the research paper.

The sequence of the data analysis section was also not up to the mark. The mentee had followed neither geographical parameters nor temporal indicators when analyzing the data. In this regard, the mentor gave some insightful comments using the track changes feature. For instance, guiding on sequence she wrote: "Somewhere much earlier in the paper you must mention that Pakistan when formed was made up of
Vol. 11 No. 022021 828011022021160 (C) Author(s)

disparate regions including Sindh, Punjab, Northwest Frontier Province and Baluchistan. Put it in the sequence. You are discussing in this paper where you start with Bangladesh first then Sindh etc... Good to have a map of these parts". After a few paragraphs when she noticed the same sequential issue, she said: "This information should be mentioned earlier in the [background] of the paper". In response to the section which did not deal with any geographical regions like other sections, she rhetorically suggested: "Should this not be mentioned before you move on to Sindh and other regions of Pakistan?". Also, to one other section of the same type, she persuasively commented: "you have Sindh, Baluchistan, N.W.F.P., now is this Punjab or ???". Accordingly, the mentee made the suggested changes to the research draft.

To improve the mentee's analytical skills, the mentor suggested him to make comparisons between the events and facts of the same nature. For instance, she suggested him to draw comparisons between the critical junctures which took place in Bangladesh and the critical junctures which are taking place in Sindh, a province of Pakistan. The mentee tried making the comparisons and came up with systematic findings.

Besides these suggestions, the mentor also gave the mentee more guiding suggestions on improving the quality of the data analysis section. First, she suggested the mentee to mention the ethnic identity of political leaders because it would be helpful in clarifying the research topic. Second, she told the mentee that the mentee should restrict his overuse of subjective analysis because it problematically associated some words/ideas with a person who, in fact, had never used the words. Third, she suggested the mentee to factcheck his content using authentic sources.

Finally, in the discussion section the mentee repeated some points which he later deleted as suggested by the mentor. Moreover, she also suggested him to check the citations against the references which the mentee had not done. Consequently, the mentee rectified the references and thus improved the quality of the paper.

After making all the suggested changes, the mentee emailed the draft naming it as 'draft 4' to the mentor.

\section{Analyzing the suggestion-based improvement of draft 4}

This draft was also commented on by the mentor using the track changes feature, and she sent it back to the mentee through email for further modifications. The process of learning and teaching has been tabulated in Table 3 .

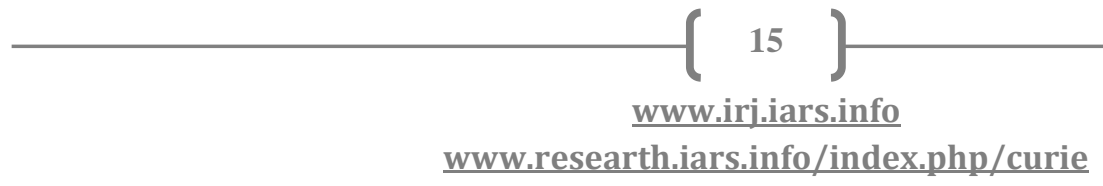


Yinternational Research Journal

p-ISSN 2202-2821 e-ISSN 1839-6518 (Australian ISSN Agency)

Table 3: Research Findings 3

\begin{tabular}{|c|c|c|c|}
\hline Sections\# & $\begin{array}{l}\text { What the } \\
\text { Mentee did. }\end{array}$ & $\begin{array}{l}\text { What the } \\
\text { Mentor } \\
\text { Suggested. }\end{array}$ & $\begin{array}{c}\text { How the } \\
\text { Mentee } \\
\text { Improved the } \\
\text { Draft. }\end{array}$ \\
\hline Introduction & $\begin{array}{l}\text { Included maps } \\
\text { from unauthentic } \\
\text { sources. }\end{array}$ & $\begin{array}{l}\text { Suggested using } \\
\text { authentic } \\
\text { sources. }\end{array}$ & $\begin{array}{l}\text { Added maps } \\
\text { from the } \\
\text { authentic } \\
\text { sources. }\end{array}$ \\
\hline Methodology & $\begin{array}{l}\text { Discussed } \\
\text { irrelevant } \\
\text { concepts. }\end{array}$ & $\begin{array}{l}\text { Asked for } \\
\text { removing the } \\
\text { concepts. }\end{array}$ & $\begin{array}{l}\text { Removed the } \\
\text { irrelevant points. }\end{array}$ \\
\hline $\begin{array}{c}\text { Literature } \\
\text { Review. }\end{array}$ & $\begin{array}{l}\text { Monolithic } \\
\text { assertiveness. }\end{array}$ & $\begin{array}{l}\text { Asked to } \\
\text { recheck. }\end{array}$ & $\begin{array}{l}\text { Modified the } \\
\text { statement. }\end{array}$ \\
\hline Data Analysis & $\begin{array}{l}\text { Did not elaborate } \\
\text { some points. } \\
\text { Did not give } \\
\text { background } \\
\text { when necessary. }\end{array}$ & $\begin{array}{l}\text { Highlighted the } \\
\text { points and } \\
\text { suggested } \\
\text { elaboration. } \\
\text { Suggested giving } \\
\text { the background. }\end{array}$ & $\begin{array}{l}\text { The points } \\
\text { elaborated. } \\
\text { Added the } \\
\text { background } \\
\text { briefly. }\end{array}$ \\
\hline $\begin{array}{c}\text { Conclusion } \\
\text { and Discussion }\end{array}$ & $\begin{array}{l}\text { Did not cite. } \\
\text { Not well-worded. }\end{array}$ & $\begin{array}{l}\text { Suggested } \\
\text { citations. } \\
\text { Suggested } \\
\text { rewording. }\end{array}$ & $\begin{array}{l}\text { Added the } \\
\text { citations. } \\
\text { Reworded the } \\
\text { highlighted } \\
\text { sections. }\end{array}$ \\
\hline References. & $\begin{array}{l}\text { Did not check the } \\
\text { style. }\end{array}$ & $\begin{array}{l}\text { Asked to check } \\
\text { the style. }\end{array}$ & $\begin{array}{l}\text { Suggestions } \\
\text { incorporated. }\end{array}$ \\
\hline
\end{tabular}

The mentee's introductory section of the draft 4 contained unauthentic sources. He had taken maps from Wikipedia without giving second thought if it was acceptable to the research community. Besides, the mentee had included irrelevant points in the methodology section which were not required there, so the mentor asked the mentee to either remove the points or modify them to look more relevant to the context. Afterwards, the mentee applied the suggestions to the methodology section and thereby improved it.

Even in the section on the literature search, the mentee resorted to subjective assertiveness. This was, of course, not up to the research standards which the mentee learnt later from the mentor. For instance, with unrestrained confidence, the mentee wrote that some of the researchers did not even mention the specific point in their research works. Then, the mentor suggested the mentee if he was sure that the scholars did not even 'mention' the points being discussed. Although what the mentee wrote was relevant, but it was much assertive in its meaning and content. Therefore, using the track changes feature the mentee interacted with his mentor: "Ma'am, all through their research paper they have approached power as if it were irresistible. They have only discussed linguistic 'marginalization'. They have not discussed how that 'marginalization' ultimately bounces back and brings about critical junctures". This type of two-way interaction made learning research techniques very effective and safe during Covid-19.
Apart from the section on the literature search, the mentee made some novice attempts in the data analysis section as well. He used some words which he did not adequately define in the section. One such word was 'apparently' which he did not explain so it did not convey the impression which the mentee intended to build up. Hence, using the track changes feature, the mentor wrote a guiding comment: "Apparently? Elaborate. Are you saying in paper they were given recognition but in reality, they were not? Can you cite from any of the data mentioned earlier?". This methodology of teaching through questions with the help of track changes feature of MS Word helped the mentee in improving the section in the data analysis. Additionally, the mentee did not give background against some key points which he had included in the data analysis section. Employing the track changes as a pedagogical tool, the mentor made an instructive comment: "Interesting but you need to give some background to this. I read...distance themselves from their language and prefer to use... So, who are the commoners? And explain, elaborate on this sentence once you include the other details I have mentioned". Accordingly, the mentee made the suggested changes using the track changes feature so that the mentor could see if he made the suggested changes.

Finally, in the discussion section the mentor asked the mentee to cite the relevant sources for the highlighted statements. Earlier the mentee had removed the repetitions from the section, but this time around he missed citing the relevant sources. Moreover, the mentor also suggested to reword a few statements which were vague, hence, the mentee reworded the statements and improved the discussion section of the paper. The mentor also suggested the mentee to check the references if these were according to the style they had decided to set up. Thus, the mentee improved upon the draft 4 and renamed it as draft 5 and emailed it to the mentor for further suggestions.

\section{Analyzing the suggestion-based improvement of draft 5}

The data has been tabulated for analysis in Table 4 .

In almost all sections of the draft 5 the mentee had incorporated all the suggested changes except the section on the references which still needed some improvement. Finally, the mentee made the suggested changes to the references and then emailed the draft naming it 'Draft 6' to the mentor. Thus, the draft was finally improved, and it was ready to be sent for publication. 
Yinternational Research Journal

p-ISSN 2202-2821 e-ISSN 1839-6518 (Australian ISSN Agency)

\begin{tabular}{|c|c|c|c|}
\hline $\begin{array}{c}\text { Sections of } \\
\text { Draft } 5 .\end{array}$ & $\begin{array}{l}\text { What the } \\
\text { Mentee did. }\end{array}$ & $\begin{array}{l}\text { What the } \\
\text { Mentor } \\
\text { Suggested. }\end{array}$ & $\begin{array}{c}\text { How the Mentee } \\
\text { Improved the } \\
\text { draft. }\end{array}$ \\
\hline Introduction. & Improved. & Accepted. & $\begin{array}{l}\text { 1. No change } \\
\text { required. }\end{array}$ \\
\hline Methodology. & Improved. & Accepted. & $\begin{array}{l}\text { No change } \\
\text { required. }\end{array}$ \\
\hline $\begin{array}{c}\text { Literature } \\
\text { Review. }\end{array}$ & Improved. & Accepted. & $\begin{array}{l}\text { No change } \\
\text { required. }\end{array}$ \\
\hline Data Analysis. & Improved. & Accepted. & $\begin{array}{l}\text { No change } \\
\text { required. }\end{array}$ \\
\hline $\begin{array}{l}\text { Conclusion and } \\
\text { Discussion. }\end{array}$ & Improved. & Accepted. & $\begin{array}{l}\text { No change } \\
\text { required. }\end{array}$ \\
\hline References. & $\begin{array}{l}\text { Did not give } \\
\text { names of some } \\
\text { scholars in } \\
\text { proper order. }\end{array}$ & $\begin{array}{l}\text { Suggested to } \\
\text { include the } \\
\text { names in proper } \\
\text { order. }\end{array}$ & $\begin{array}{l}\text { Reset according } \\
\text { to the required } \\
\text { style in } \\
\text { ascending order. }\end{array}$ \\
\hline
\end{tabular}

\section{Discussion and Concluding Remarks}

During the pandemic, the mentee learnt writing a research paper using email, WhatsApp, and MS Word track changes feature. It was a practical way of learning in which the mentor facilitated the mentee with guiding suggestions and feedback all through the process using the online platforms and the track changes tool. Under the mentor's online supervision, the mentee learnt how to write abstract, introduction, methodology, literature review, data analysis, discussion, and conclusion of a research paper. He also learnt different styles of giving citations and references in a research paper. Moreover, since the feedback was written on the mentee's paper, the mentee was able to use it at any time. Over the process of writing the research, the mentee would often look at the feedback and successfully drew insightful guidance from it. The process of learning through the online means was both safe and effective.

The mentor systematically evaluated all the six drafts which the mentee produced. She made sure he made his best efforts to improve both the content and structure of the paper. They also used WhatsApp calls to discuss the areas which the mentee needed to improve. The process of learning through suggestions, feedback, and evaluation was a continuous process which lasted over a month. This period of continuous learning has ameliorated the mentee's research doing skills. The mentee can now write a systematic research paper in accordance with the requirements of different SCOPUS/ISI indexed journals. The mentor also taught the mentee to know his academic setting and thereby write a research paper which has much more chances of publication in the solid journals.

This research draws its inspiration from the fact that online education has been well received among students. Since research is a part and parcel of higher education, we decided
Vol. 11 No. 022021 828011022021160 (c) Author(s)

to explore how effectively it can be learnt using online means. Our results build upon experiential methodology by showing that online learning is effective.

The advice provided by the mentor was provided in a facesaving manner. The mentor used several rhetorical questions to save the face of the adult learner. Although there were times when the same error was repeated despite earlier advice on the same issue in polite written discourse such advise can be given in a non- threatening manner. The pandemic has resulted in much written feedback, which if diplomatically given, can encourage mentees to persevere till the mentor and mentee are fairly satisfied with the finished product.

Finally, we are of the view that in this pandemic both mentors and mentees should rely on online means and track changes feature to make learning both effective and safe. In this new normal, students and teachers should maintain physical distance and collaborate in the constructive process of learning using email, WhatsApp, track changes and other online means at their disposal. Thus, leaning in the times of pandemic can be made both safe and effective.

\section{REFERENCES}

[1]. Bhuwandeep, \& Das, Piyusa. Emerging trends of emergency remote education in COVID-19: A thematic literature review. Journal of Humanities and Social Sciences Research, 2((S)), 5-10. doi: 10.37534/bp.jhssr. 2020.v2.ns. id1069.p5. 2020.

[2]. Byrom, Nicola. COVID-19 and the research community: The challenges of lockdown for earlycareer researchers. 2020. Retrieved from https://elifesciences.org/articles/59634. Accessed 26 October 2020.

[3]. Khezrimotlagh, Dariush. Academic challenges and opportunities during the 2020 pandemic. Journal of Humanities and Social Sciences Research, 2((S)), 1116. doi: 10.37534/bp.jhssr. 2020.v2.ns. id1062.p11. 2020.

[4]. Patra, Sudhakar., \& Sahu K, Kabita. Digitalization, online learning, and virtual world. Journal of Humanities and Social Sciences Research, 2((S)), 4552. doi: 10.37534/bp.jhssr. 2020.v2.ns. id1066.p45. 2020.

[5]. Jagathkar, A. and Jain, D., Digitized Education: A New Social Divide between Rural and Urban India, IARS' International Research Journal. Vic. Australia, 10(1). doi: 10.51611/iars.irj.v10i1.2020.115. 


\section{Manuscript Processing Footprints}

\section{A. Journal Volume/Issue Details}

This manuscript it published in Vol. 11 No. 022021 issue of IARS' International Research Journal (I'IRJ).

This is a Peer Reviewed (Refereed) International Journal published by IARS' Press Australia (International Association of Research Scholars) The Volume/Issue is a regular issue of the journal published in August 2021 Available at: https://researth.iars.info/index.php/curie.

\section{B. Copyright, License, and Publishing Rights}

- IARS' Press Australia (International Association of Research Scholars) respects the rights of the authors of research content published with IARS' International Research Journal. The "First Publication Rights" (FPR) to the original work accepted for publication at IARS' International Research Journal is granted to the Publisher of the Journal but copyright for all work published in the journal is retained by the author(s). Works published in the Journal is distributed under a Creative Commons Attribution 4.0 International License (CC B Y 4.0). (This license lets others distribute, remix, adapt, and build upon your work, even commercially, as long as they credit you for the original creation. This is the most accommodating of licenses offered. Recommended for maximum dissemination and use of licensed materials.)

- After publishing the content with IARS' International Research Journal, the author holds complete right on the content for its amendments and reuse in any form. IARS' International Research Journal confirms that author(s) holds the copyright of the content.

- $\quad$ Author(s) grant(s) permission for their work to be indexed in part/full form in commercial and non-commercial indexes. Author(s) grant(s) permission for their work to be harvested in part/full form in commercial and non-commercial archives and distributed through them. Author(s) grant(s) permission for their work to be translated in part/full form in any language and republished and redistributed. Author(s) may enter into separate, additional contractual agreements for the non-exclusive distribution of the published version of the work, with an acknowledgement of its initial publication in this Journal.

- It is the responsibility of the author(s) to secure all necessary copyright and/or permissions for the use of third-party content in their manuscript(s). Author(s) have declared the same at the time of submission of manuscript and 'may also be required' to provide written evidence of this permission anytime in case required for any purposes.

- Publications Ethics and other Terms and Conditions as mentioned on official website of IARS' International Research Journal.

\section{Last Plagiarism Report}

Settings: Similarity of 09 words in a row has been considered plagiarized.

Plagiarized (0\%) Unique (100\%)

\begin{tabular}{|l|l|}
\hline Date & Aug 13, 2021. \\
\hline Words & 11 Words Plagiarized / Total Words 5971. \\
\hline Source & 1 Source(s) Identified. \\
\hline Remarks & No similarity found, your document looks healthy. \\
\hline
\end{tabular}

\section{Processing Track}

\begin{tabular}{|l|l|}
\hline Date of Submission & 06 March 2021 \\
\hline Date of Final Review & 28 June 2021 \\
\hline Date of Acceptance \& Schedule & 15 August 2021 \\
\hline Date of Publishing & 29 August 2021 \\
\hline
\end{tabular}

